\title{
聴性電気反応検査に抢けるフーリエ変換法利用の現況
}

山形大学医学部耳鼻咽喉科学教室（主任：小池吉郎教授)

青 柳 優

\section{THE CURRENT STATUS OF THE USE OF FAST FOURIER TRANSFORM FOR AUDITORY EVOKED RESPONSE}

\section{MASARU AOYAGI, M.D.}

Department of Otolaryngology, Yamagata University School of Medicine, Yamagata

The current status of the application of the fast Fourier transform (FFT) for the auditory evoked response was summarised under for items of importance to the auditory brain stem response (ABR) as follows.

(1) Digital filter: The most common way to use FFT, which facilitates quick isolation of fast and slow components from data of the same ABR wave. In addition, the proper setting of digital filter increase the rate of detection of waves II and IV, the frequencies of which have conventionally been considered to be low.

(2) Power spectrum analysis: It is difficult to obtain clinically significant information from power spectrum in the present situation. However, it seems significant in ABR to isolate and analyze slow, middle (tentative name) and fast components from the Fourier components revolving around each peak of the power spectrum with a three-peak pattern by inverse fast Fourier transform (IFFT).

(3) Cross correlation function: This method is the way to analyze the relationship between two signals from the viewpoint of the phase. Clinical application including application to the diagnosis of multiple sclerosis, application to automatic detection for ABR, etc. are expected in the future. (4) Phase specteral analysis: The synchrony measure method (Fridman, 1982) is one of the phase spectral analysis made by means of FFT. In this method, phase variance for selected Fourier components are calculated among the averaging groups of 200 sweeps under the same stimulating conditions, in order to determine the presence or absence of response by the degree of the timelocked condition of the Fourier components for stimuli. Its clinical application to automatic evaluation of $A B R$, etc. is being studied.

Key words：聴性電気反応，フーリ工変換，デジタルフィルター パワースペクトル解析，位相スペクトル解析

A $89-0478-00082$

はじめに

近年, 聴性電気反応は神経科, 脳外科領域を含めて 非常に一般的な検查となってきており，特に聴性脳幹 反応 $(A B R)$ は広く臨床に応用されるようになってき

山形大学医学部耳鼻咽喉科学教室開满 10 周年記念諭文 た。これらはいずれも刺激に対して脳波上（back ground EEG）に現われる微細なる反応波形を㭘出す るものであるが，最も反応榆出率の安定している $\mathrm{ABR}$ でも $\mathrm{S} / \mathrm{N}$ 比は非常に低い. $\mathrm{S} / \mathrm{N}$ 比を高める手法 として, 一般的に(1)平均加算法, (2) (アナログ) 71 ルター, (3アーチファクト・クリア（ユニット）など 
が用いられている。

平均加算及びフィルターは ABR 波形を検出する上 で基本的な手法であるが，いずれも限界がある。平均 加算は ABR の場合，一般的に 1000〜2000回の加算を 行う.症例にもよるが, 500 回程度の加算では反応波形 検出の安定性は低下するが, 2000 回以上の加算をして も，それ以上 $\mathrm{S} / \mathrm{N}$ 比の改善を期待できないだけでな く、いたずらに検查時間を長くすることになる。アナ ログフィルターは low pass filterまたはband pass filter が用いられるが, 不要な周波数成分を完全に除去 しようとすればする程，通過带域を狭めねばならず， また，減衰傾度 (dB/oct) を上げ柿ばならい。通過 帯域を狭め，減衰㑯度を上げれば聴性電気反応の最も 重要なパラメーターである潜時に影響が現われてく る.

一方近年, コンピューターの普及が著しくほとんど の医療施設て用いられるようになり，聴性電気反応検 查にデジタルィルターの使用が一般的になりつつあ る. デシタルフィルターは一般的には(1)非巡回型デジ タルフィルター, (2巡回型デジタルフィルターがある. 非巡回型デジタルフィルターにはZ変換による綐続 形構成のものとフーリエ変換 (fast Fourier transfor$\mathrm{m}=\mathrm{FFT})$ による方法があり，巡回型デジタルフィル ターには種々の構成のものがあるが, 各種 Z変換を利 用する ${ }^{9) 27)}$.

この他，平均加算波形を見やすくする方法として移 動平均法があるが，これは low pass filter としての働 きしかない。これに対し FFT を応用する方法は潜時 の変化を来すことなくどの周波数ても比較的容易に除 去出来ることから，理想的なフィルターと言える。 FFT は元々音声研究の分野て周波数分析, 相関係数な どの分析法に応用されて発展して来たが, 近年種々の デシタル信号処理に利用されるようになってきており ${ }^{27)}$, 聴性電気反応へも応用されるようになってきた。 こでABR を中心に聴性電気反応へのFFT 利用の現 況について概説する。

\section{方法}

当科では平均加算その他のデー夕処理に平均加算装 置でなく医用コンピューター,シグナルプロセッサー $7 \mathrm{~T} 17$ (日本電気三栄製) 用いている。このコンピュー ターの特徵は平均加算処理の他, 移動平均法, FFT, 逆フーリエ変換（inverse FFT=IFFT）など, 医用信 号処理に便利な特殊命令が多く提供されて放り, 誰で
も BASIC 言語により比較的容易に FFT などを検査 に利用できることである。

\section{聴性電気反応への FFT の応用}

フーリエ変換は，時間軸における量の変化のしかた を，周波数軸において周期的な見方でとらえたもので あり，その理論の基礎は１700年代にさかのほる，本理 論の創始者フーリエ (Jean Baptiste Joseph Barcon de Fourier）はフランスの数学者, 物理学者で後に県 知事となり行政官としても功績のあった学者で，周期 関数が三角関数に展開できることを証明し，それを熱 伝導論に応用した ${ }^{25}$.これが FFT の始まりである。今 日我々が比較的容易に FFTを利用できるようになっ たのは、コンピューターの発達と離散フーリエ変換と いうデジタル処理に適した計算法が開発されたことに よる.この離散フーリエ変換をコンピューターで行う ときの計算法を1965 年 CoolyとTukey が開発した 27).このアルゴリズム及びそれを改良したものが, 今日 のFFTと言われているものである.

本論文の趣旨は FFT の聴性電気反応検查への利用 の現況を概説することにあるので，数学的なことは成

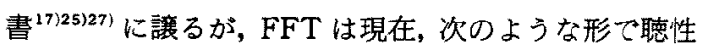
電気反応に応用されている。

1. Digital filter

2. Power spectral analysis

3. Cross correlation

4. Phase spectral analysis

現在のところ我が国では FFT は聴性電気反心応領 域ではデジタルフィルター及びパワースペクトルとし てのみ応用されており，これ以外では我々の施設で Phase spectral analysis $し て$ Fridman $の$ Synchrony measure 法 $^{1415)}$ を試用しているのみであ る2. 以下, 各々の応用法について概説する。

1. デジタルフィルター

生体電気現象の記録にはフィルターは不可欠のもの であり，市販の測定装置には必ずアナログフィルター が組み込まれている。アナログフィルターには(1)演算 増幅機（OP Amp）と抵抗，コンデンサーを用いた方 法（能動フィルター）と(2)一次素子（抵抗，コイル， コンデンサーによる方法) (LCRフィルター)があるが 27),いずれの場合もこれを通過することによって, 周波 数により滅衰が異なるのみならず，位相のずれも生じ てくる。従って，低域または高域遮断周波数を低くす れば潜時は延長し，逆に高くすれば短縮する（図 1)。 


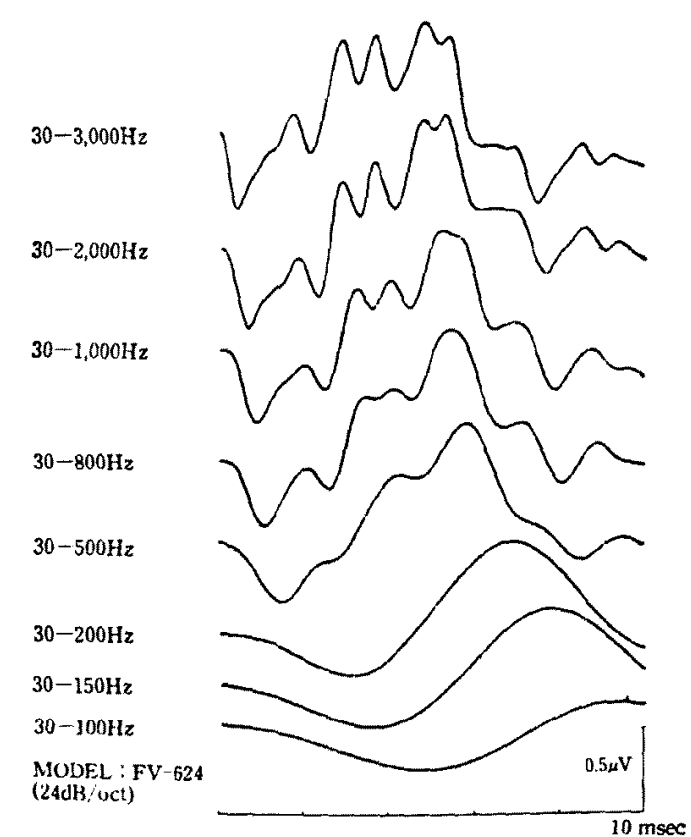

图1 A B R 波形に及ぼすアナログフィルターの影響 低域遮断周波数を $30 \mathrm{~Hz}$ として, 高域遮断周波 数を種々変化させた場合のA B R 波形.

(杏川銀一郎による)

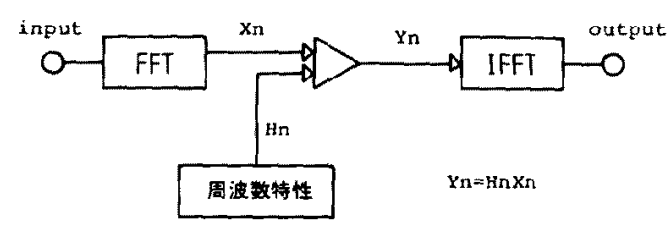

図 2 FFTを用いたデジタフィルタ一の構成

この傾向はフィルターの減衰傾度 (dB/oct) によって も異なり，不要な周波数成分をシャープに遮断しよう として隇咅㑯度の大きいフィルターを用いるほどこの 傾向は大きくなる。

これに对してデジタルフィルターの利点としては， (1)伝達関数を次に述べるような ideal filterに近い特 性にした場合には位相のずれのないこと，(2)高精度で あること, (3)フィターの伝達係数が比較的容易に変 更できることなどがあげられる27. FFTによる非巡回 型デジタルフィルターの構成は図 2 に示すが，原理的 には入力波形を FFTしたものと希望するフィルター の周波数特性との積を計算し，次にこれをIFFTする ことによって出力波形を得るものである27. ここで周
波数特性を規定する伝達関数には種々のものがある が，我々は単純に通過带域の下限周波数 $\left(\mathrm{f}_{1}\right)$ と上限周 波数 $\left(\mathrm{f}_{2}\right)$ を決め, 周波数の領域で $\mathrm{f}_{1}$ 以下及び $\mathrm{f}_{2}$ 以上 に0を乗じ $\mathrm{f}_{1} \sim \mathrm{f}_{2}$ 間には $\mathrm{I}$ を乗じるという伝達関数 を用いている。この場合，非常に減衰傾度の大きい》 イルターとなるが，その特性はサンプリング点数 (N) とサンプリング・タイム（ $\Delta \mathrm{t} ）$ により規定される周波 数分解能 $(1 / \mathrm{N} \Delta \mathrm{t})$ により影響される．周波数分解能 より細かく通過带域を変えることは出来ないし，余り 分解能を広くとると急峻な減衰傾度が得られない。

このようにデジタルフィルター機つかの演算から 成るために若干の時間を要することが欠点であり，コ ンピューターの演算速度によっても異なるが，アナロ グフィルターのように平均加算の前にかけようとする と，刺激音間隔に制限を受け，場合によっては実時間 処理が困難であり, off line でデー夕処理をしなけれは ならないこともある。事寒，我々の使用しているコン ピューターでは, signal BASIC という一種の BASIC 言語でデジタルフィルターをプログラミングしている ということが大きいが, on line で平均加算の前にこの デジタルフィルターをかけること出来ず，もしそう しようとすれば，かなり刺激音間隔を長くしなければ ならない、そこて，我々はもっばら通過帯域を広くと つたアナログフィルターを用いて平均加算した波形テ ータについて同様の演算を行い, デジタルフィルター
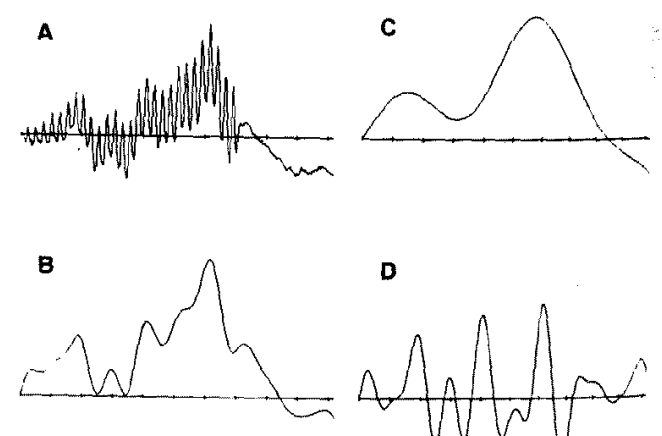

D

图 3

4kHz Tone burstに対するABR波形
A： 80〜3000Hzのアナログフィルターのみによる記镜
B： $80-1500 \mathrm{~Hz}$ のデジタルフィルターをかけ什記録
C： 0 $300 \mathrm{~Hz}$ のデジタルフィルターをか什犬記録
D : 500 1500Hzのデシタタフィルターをかけな記銶 
$L C F=40 \mathrm{~Hz}$

$L C F=40 \mathrm{~Hz}$

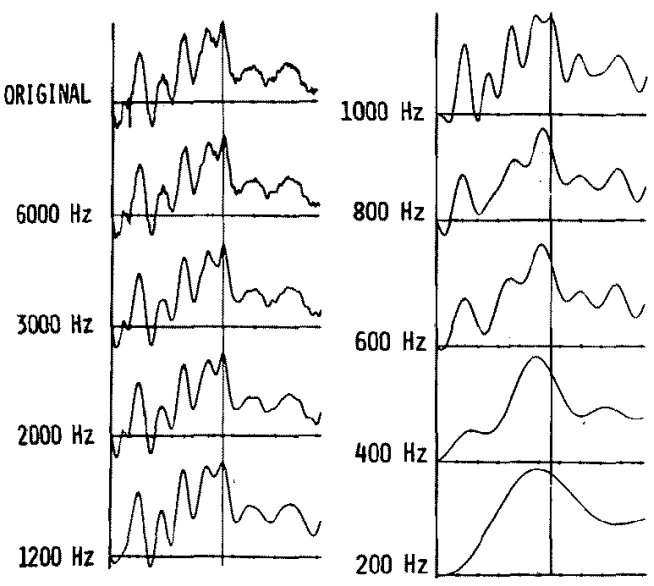

图4A B R 波形に及はすデジタルフィルターの影䈍 低域遮断周波数を $40 \mathrm{~Hz}$ として，高域遮断周波数 を種々変化させた場合のA B R 波形。

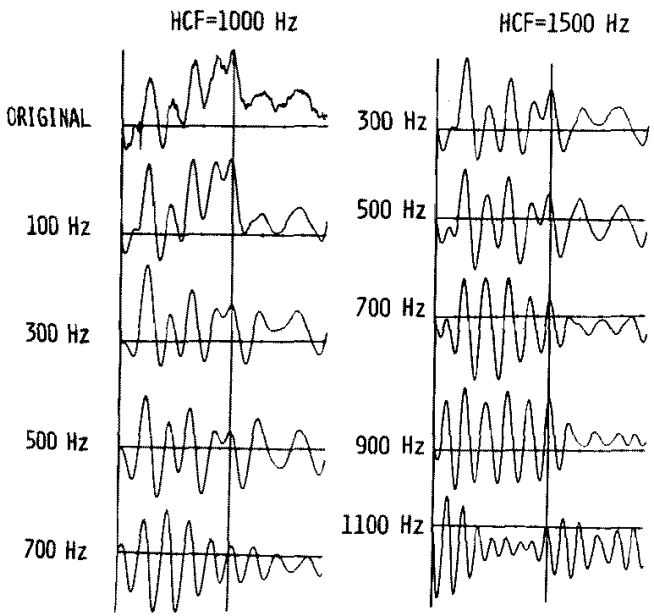

图 5 A B R 波形に及ぼすデジタルフルルーの影響 高域遮断周波数を 1000 または $1500 \mathrm{~Hz} と し て ，$ 低城遮断周波数を種々変化させた場合のA B R 波形。

として利用している．従って，平均加算の前にデジタ ルフィルターを使用した場合と後に使用した場合の出 力波形の善異についてはわからないが, 後者でもFFT を利用した場合の利点は十分にあると考える。

図 3 に $4 \mathrm{kHz}$ Tone Burst (90 dB nHL) にたいす るABR 波形とそれに対しFFTによるデジタルフィ

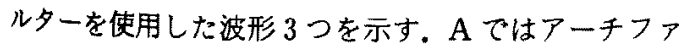
クトに埋もれて I〜V 波まで替時の測定は不可能であ るが, Bではアーチファクトは全く除去されれている。
またデジタルフィルターの通過带域を狭めることに より，同一の波形デー夕から緩徐波成分と速波成分を 求めることが出来る，特に速波成分においては，図 3 のBとDのIV 波を比較するとわかるように，通過带 域を適当に絞ることにより，従来では正常人でも出現 性の低かった II 波・IV 波をより高率に同定出来るよ うになった。

図 4 は Low Cut Filter (LCF) $=\mathrm{f}_{1}$ を $40 \mathrm{~Hz}$ に固定 して, High Cut Filter $(H C F)=f_{2}$ を変化させた場合 であり，HCF 6000〜 $1000 \mathrm{~Hz}$ までは各波潜時にほと んど変化のないことがわかる。灾た，HCF 400 または $200 \mathrm{~Hz}$ では緩徐波成分のみが譛められる。図 5 は逆に HCF を $1000 \mathrm{~Hz}$ まなは $1500 \mathrm{~Hz}$ に固定し，LCF を変 化させた場合であるが，I〜V 波については LCF 100 〜700 Hz までは潜時变化が活とんどないのがわかる。 しかし，LCF を更に上げると，ほとんど I V 波とは 見えない波形の連続となり，IV・V 波については更に その傾向は強い，従って，速波成分を同定するには， I V V 波のみが目的であれば LCF $=600 \sim 700 \mathrm{~Hz}$ がよ く，VI・VII 波も含めて取り出そうとすれば, 300〜500 HzにLCFを下げなければならないと考える。

緩徐波成分と速波成分を分割するためのフィルター 設定值としては，市川，江原ら ${ }^{10111)}$ は緩徐波成分は 40 $\sim 120 \mathrm{~Hz}$ または 40〜160 Hz，速波成分は 200〜 1400 $\mathrm{Hz}$ とし，高木ら ${ }^{36)}$ は緩徐波成行は $50 \sim 300 \mathrm{~Hz}$ ，速波 成分は $400 \sim 1500 \mathrm{~Hz}$ としている。我々は前述のよう な所見と次㖽で述べるパワールペクトルの所見とか ら，緩徐波成分は $0 \sim 300$ ないし $400 \mathrm{~Hz}$ とし，速波成 分は 300 ないし $400 \mathrm{~Hz}$ から 1200 ないし $1500 \mathrm{~Hz}$ が 適当と考えている。

このように FFTによるデジタルフィルターを利用 することにより, 同一波形デ一タから潜時の変化を来 たすことなく，緩徐波成分と速波成分を分割すること が出来るのみならず，通過带域を狭くすることにより， 特に速波成分では各波の検出率を上げることが出来る など, FFTの利用は ABR 検查にとって多大な利点を 有し、これにより ABRの臨床検查としての精度を高 めることが出来ると考える。

頭頂部緩反応・頭頂部中間反応についても同樣にデ ジタルフィルターの有用性は論じられており, 江原 ${ }^{8)}$ は FFTを用いた非巡回型デジタルフィルターを加算 前に用いて頭頂部緩反応を分析し，成人て $17 \%$ ，幼見 で25\%に検出率が向上したと報告しているまたここ の際3 -9 Hzの通過带域とするデジタルフィルター 
が頭頂部緩反応の検出に有効であったという．山本 ${ }^{38)}$ も加算後の波形に対してデジタルフィルターを用いて 検討しているが, $10 \mathrm{~dB}$ の音刺激時に反応波形を構成 する周波数成分は $3 \sim 9 \mathrm{~Hz}$ であり, 安静・開眼時自発 脳波加算波形の周波数分析では $2 \mathrm{~Hz}$ と反応波形構成 周波数帯域とずれているとし、デジタルフィルターの 有用性を示唆している.

2. パワースペクトル

パワースペクトルは FFTによる周波数分析で実数 部 $(\cos )$ と虚数部（sin）に分けられた周波数領域のデ ー夕系列の各々を2 乗して合計することにより得られ る.ABR 波形のパワースペクトル分析は Elberling ${ }^{13)}$, Kevanishvilii ${ }^{23)}$ 以来既に多くの報告がある. ABR 波 形の主要周波数成分が $250 \mathrm{~Hz}$ 以下であるとした Elberling ${ }^{13)}$ 以外は, 十分な刺激音圧では 3 つのピーク に分かれるというのが大方の意見であ る2123325)28333/34)37). 我々のデー夕からも $300 \sim 450 \mathrm{~Hz}$, $600 \sim 800 \mathrm{~Hz}, 1200 \sim 1500 \mathrm{~Hz}$ に谷が見られる 3 峰性を 示しており（図 6), $50 \mathrm{dBnHL}$ 程度の音圧では 600 $\sim 800 \mathrm{~Hz}$ 以上のパワーが減弱してくるという結果が 出ている.これは鈴木ら ${ }^{3334)}$ の報告, すなわちピーク I $50 \sim 150 \mathrm{~Hz}$, ピーク II $500 \sim 600 \mathrm{~Hz}$, ピーク III 1000 〜 $1100 \mathrm{~Hz}$ とほほ一致するものである。

ABR のパワースペクトルが 3 峰性であるという事 実は, 他のほ乳類でもほほ共通の所見であり, 我々の

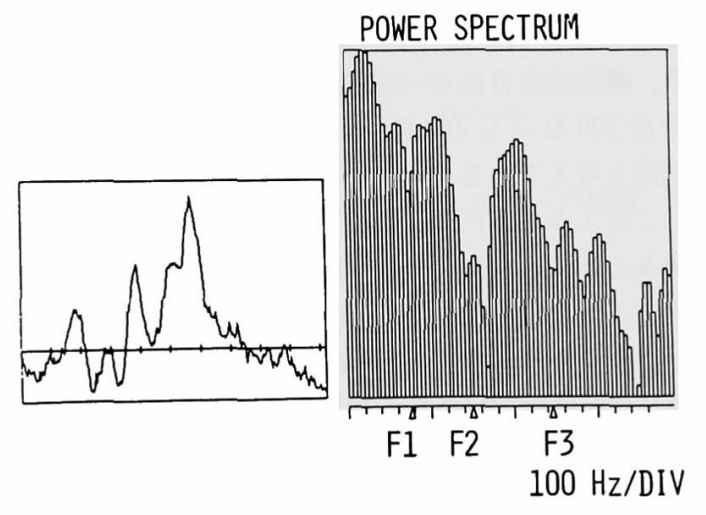

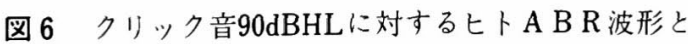
そのパワースペクトル

パワースペクトルは 3 峰性を示し, F 1, F 2, $\mathrm{F} 3$ は各々間の谷の周波数を示す.

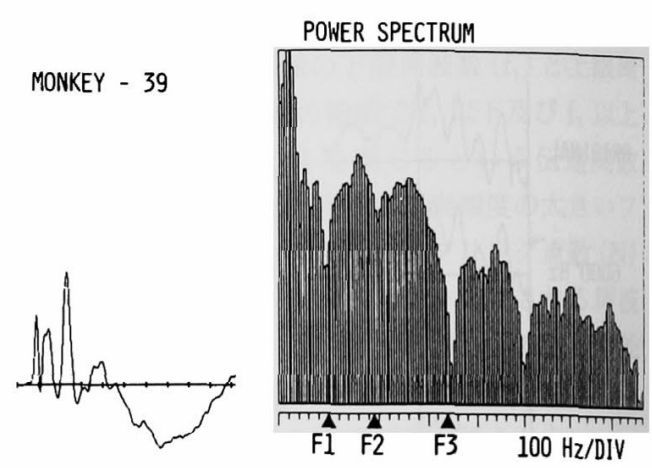

図7クリック音100dBSPLに対するサルA B R 波形 とそのパワースペクトル

DOG - 001
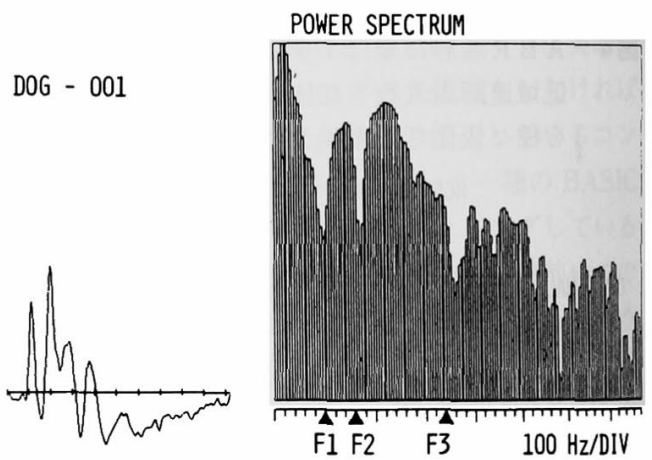

図8 クリック音100dBSPLに対するイヌABR波形 とそのパワースペクトル
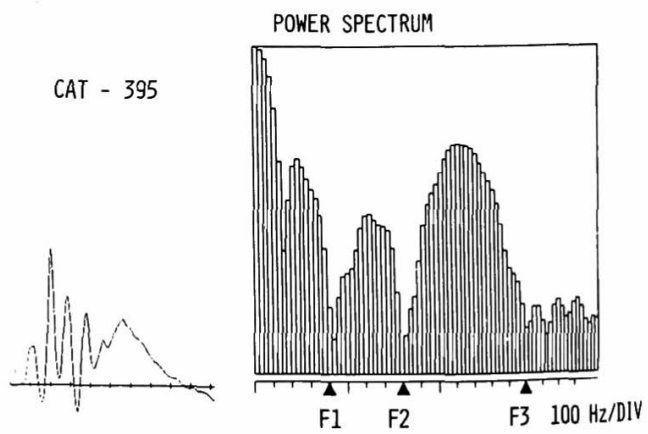

图 9 クリック音100dBSPLに対するネコABR 波形 とそのパワースペクトル 


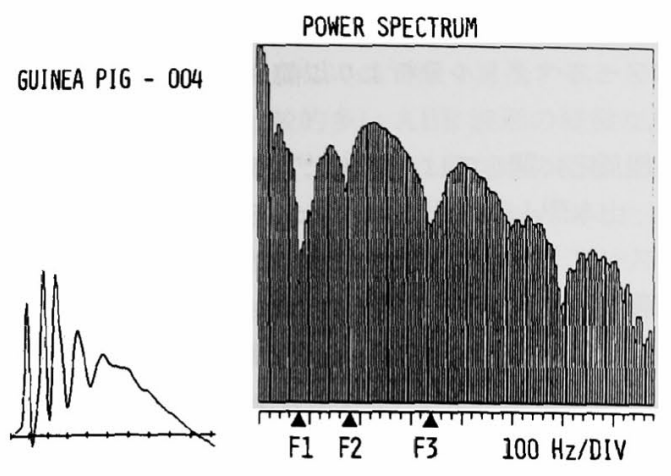

图10クリック音100dBSPLに対するモルモット A B R 波形とそのパワースペクトル

\section{F59056}
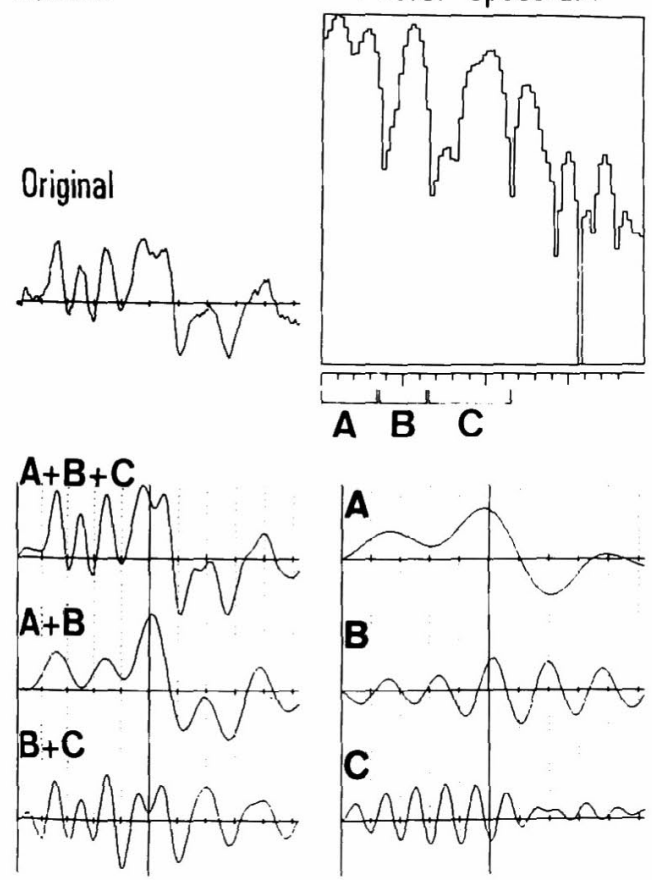

龱11 典型的七トA B R 波形とそのパワースペクトル， 及U゙各種デジタルフィルターをかけな波形

$\mathrm{A}$ はいわゆる䌅徐波成分, $\mathrm{B}+\mathrm{C}$ は速波成分を 示す. $\mathrm{B}$ は中間波成分 (仮称)

検討したサル, イヌ，ネコ，モルモットでは各々ピー クの位置は異なるもののいずれも 3 峰性のパワースペ クトルを示した（図 7〜10).
$\mathrm{ABR}$ 波形は緩徐波成分と速波成分よりなるといわ れており，鈴木のピーク I が緩徐波成分に，ピーク II と III が速波成分に相当することは既に衆知のことで あり, 前にも述べた。図 11 は 3 つの周波数成分を $\mathrm{A}$, $\mathrm{B}, \mathrm{C}$ とした時, $\mathrm{A}, \mathrm{B}, \mathrm{C}$ の各々及び, $\mathrm{A}+\mathrm{B}, \mathrm{B}+\mathrm{C}$ と $\mathrm{A}+\mathrm{B}+\mathrm{C}$ の各周波数成分から IFFTにより求めた 波形である. $\mathrm{A}+\mathrm{B}+\mathrm{C}$ が日常検查に用いている高域遮 断フィルターのみをかけた $\mathrm{ABR}$ 波形であり，A が緩 徐波成分, $B+C$ が速波成分と呼ばれるものである。こ のように同一の ABR 波形からデジタルフィルターに より一定の周波数成分のみから構成した波形を並べて 見ると, 幾つかの興味ある所見に気付く.

第 1 に, C の成分では潜時から見て $\mathrm{ABR}(\mathrm{A}+\mathrm{B}+$ C)の I V 波に相当する波形が見られるが，III 波に相 当する波の振幅が最も大きく，その前後の波で振幅は 小さくなる傾向がある.

第 2 に，Bの成分では I，III，V，VI，VII波に近い 潜時の波が見られ，これらのI， III波に相当する陽性 波の間（陰性波）が $\mathrm{ABR}(\mathrm{A}+\mathrm{B}+\mathrm{C})$ のII 波に，III， $\mathrm{V}$ 波に相当する陽性波の間 (陰性波) が $\mathrm{ABR}(\mathrm{A}+\mathrm{B}+$ C)のIV波に大体一致していることに気付く.しかもこ れら潜時の関係は症例によって一様でない. 正常者の $\mathrm{ABR}$ 波形の中にII波，IV波の出現しないものがある が, この現象はパワースペクトルとデジタルフィルタ 一の観点からは, Lang ${ }^{34)}$ も同様の所見を述べているよ うに，ここに述べた第 2 の現象により説明される。す なわち，Cの成分のII波，IV波に相当する波の潜時が， Bの成分の I 波, III波に相当する波の間の谷及びII波， $\mathrm{V}$ 波に相当する波の間の谷の潜時と一致した場合に, $\mathrm{ABR}$ 波形 $(\mathrm{A}+\mathrm{B}+\mathrm{C})$ のII 波, IV 波が欠如するのであ り, 少しでも互いの潜時がずれていれば，それらの位 相の一致の程度と振幅の大きさに応じて, II 波, IV波 が出現することになる。図 12 にII波, IV波が出現して いない $\mathrm{ABR}$ 波形の例を示す。

これらの現象が臨床的にどのような意義を有するか は今後の問題だが, ABR 波形のパワースペクトルが 3 峰性である事実を考えると，このように ABR 波形 を $\mathrm{A}, \mathrm{B}, \mathrm{C}$ すなわち, 緩徐波, 中間波 (仮称), 速波 の3つの成分に分けて論じることも，あながち無駄な こととも言えないと考える.

また，これらの所見から我々が日常見ている ABR 波形の I, III 波は300 1200Hz，II，IV 波は 700 $\sim 1200 \mathrm{~Hz}, \mathrm{~V}, \mathrm{Vl}, \mathrm{VIl}$ 波は $0 \sim 1200 \mathrm{~Hz}$ の周波数成分か らそれぞれ成り立っているとも言える.しかしながら， 

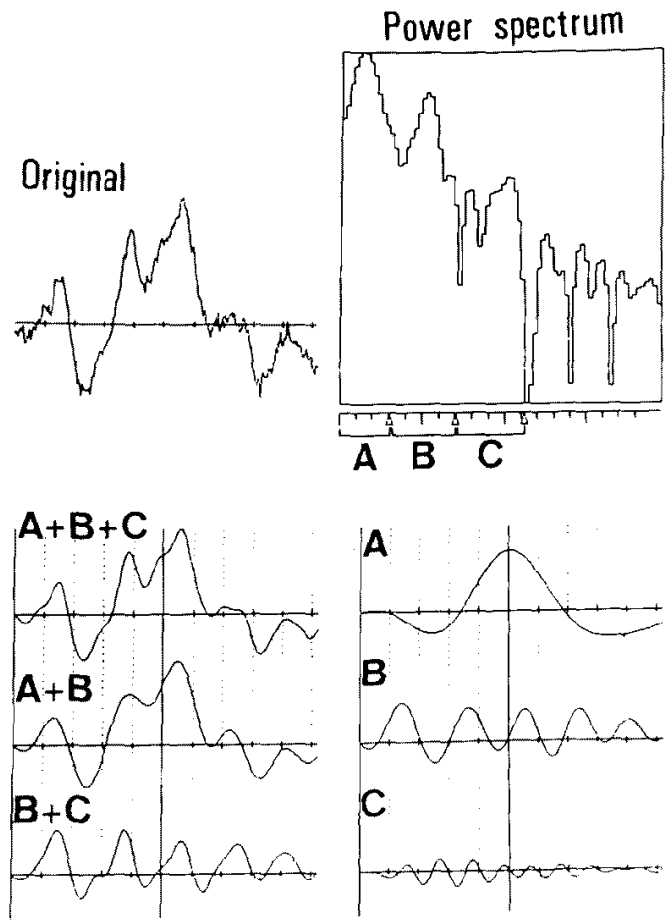

図12 II 波とIV波の出現していないA B R 波形とその パワースペクトル，及び各種デジタルフィルタ 一を加けた波形。

$\mathrm{B}$ 成分の振幅がC成分の振幅より著名に大きい。

時間軸領域のデータである $\mathrm{ABR}$ 波形の各波と周波数 領域のデータであるパワースペクトルのピークを対応 するものとして諭じることには慎重でなければならな い。例えば，聴神経腫瘍症例などて，I波のみ出現し ている場合などの異常な ABR 波形についてのパワー スペクトルについて論じる場合，殊に慎重でなければ ならないと考える。著者は基本的には，沖津ら ${ }^{28)}$ の言 うように, ABR のパワースペクトルからのみでは現 在のところ ABR 反応を有無を予測することは出来な いと考えて招り，周波数領域のデータであるパワース ペクトルから時間軸領域のデータである ABR 波形の 潜時や振幅から得られる情報以上に臨床的に有意義な 情報は現段階では得られないと考えている。しかし， 今後より詳細な，または何らかの巧妙な手段によりパ ワースペクトル所見から，䠛床的に有意義な情報を引 き出し得る方法が考案されることも期待でき，今後と もABRのパワースペクトルによる検討は統けられる ベきと考える，一方，緩反応・中間反応に対するパワ ースペクトル分析は，これらの反応の检討が $\mathrm{ABR}$ 上
り以前から行われていることもあり，ABRに対する パワースペクトル分析より以前から報告がなされてい ろ.

緩反応に関しては, Davis ${ }^{6)}$, 曾田 ${ }^{32)}$, 加藤22), 末続 ${ }^{321}$ ，山本 ${ }^{38)}$ ，市川 ${ }^{18)}$ らの報告があり，音刺激時のパワ 一スペクトルのピークは Davis 0 $12 \mathrm{~Hz}$, 曾田 $5 \mathrm{~Hz}$, 加藤 3 4 $4 \mathrm{~Hz}$, 末続 $3.33 \mathrm{~Hz}$ ，山本 $4 \mathrm{~Hz}$ でほほ同様の結 果を得ている。山本はこれらの結果から反応波形構成 周波数のパワースペクトルの大小によって反応の有無 を評価出来るであろうとしているが，低音圧刺激時に は反応波形構成周波数でも無刺激時パワーとの間には つきりした差が認められない場合も少なくないとして いる.

\section{3. 相関関数}

FFT の利用法として, 次に相関関数があげられる。 相関関数には自己相関関数 (Auto-correlation) と相互 相関関数（cross correlation）があり，いずれも FFT を利用すれば比較的容易に計算される。聴性央気反応 への応用としては auto-correlation は見られないの で,ここでは cross correlationについて述へる。

cross correlation は 2 つの信号間の関係を位相（時 間のずれ）という立場からみるもので，クロスパワー スペクトルをIFFTすることで得られる。クロスパワ 一スペクトルとは 2 信号間でどのような周波数成分が どのくらいの強さの割合で影響し合っているかを示す もので，2つの信号より FFTにより得られた各々の 実数部と虚数部を相互に掛け合わせることにより得ら れる。すなわち，例えば各周波数成分においてXとい う信号の実数部を $\mathrm{Xa}$, 虚数部を $\mathrm{Xb}$ とし, $\mathrm{Y}$ という信

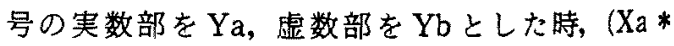
$\mathrm{Ya})+(\mathrm{Xb} * \mathrm{Yb})$ を実数部のデータ, $(\mathrm{Xb} * \mathrm{Ya})-$ $(\mathrm{Xa} * \mathrm{Yb})$ を虚数部のデータとしてIFFTを行うこ とにより計算される。

ABRへのcross correlation の応用は Elberling $(1979)^{22)}$ 门報告が最初であろう。現在，国内ではこれ をABR へ応用した報告はなく，外国の報告では他に Arslan $^{33}$, Barajas ${ }^{4}$, Maurizi $^{26)}$, Paludutti ${ }^{29)}$ などがあ る程度である。Arslan ${ }^{33}$ を除いていずれも何人かの正 常人の ABR 波形を平均加算して得た基染となる ABR 波形 (normal template) を個々の症例の ABR 波形との間での cross correlation について模討して いるもので，その多くは多発性硬化症の診断への底用 てある。他には Maurizi i ${ }^{26)}$ が中枢性耳鳴の湸断に庞 を試み，一方， Arslan ${ }^{3}$ は cross correlationを用いて 
一種の binaural interaction について検討している.

我々には本法の経験はないので深く言及することは 避けるが, 個人差の比較的多い ABR 波形の軽微な異 常を検出する方法として, ABR 自動判定の指標とし $\tau$, 今後次項で述べる Phase spectral analysis ととも に臨床応用への検討が期待される。

\section{Phase spectral analysis}

聴性量気反応の phase spectral analysis は Sayers

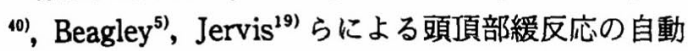
解析に始まる。これは加算前の脳波に対して FFTを 行い, 同一刺激条件下の幾つかの波形群の間での一定 の Fourier component (周波数成分) の phase varianceを求めるもので, これの值が小さい時はその周波数 成分が音刺激に対して time-locked であり, 聴性反応 である事を示し, background EEG の周波数成分に対

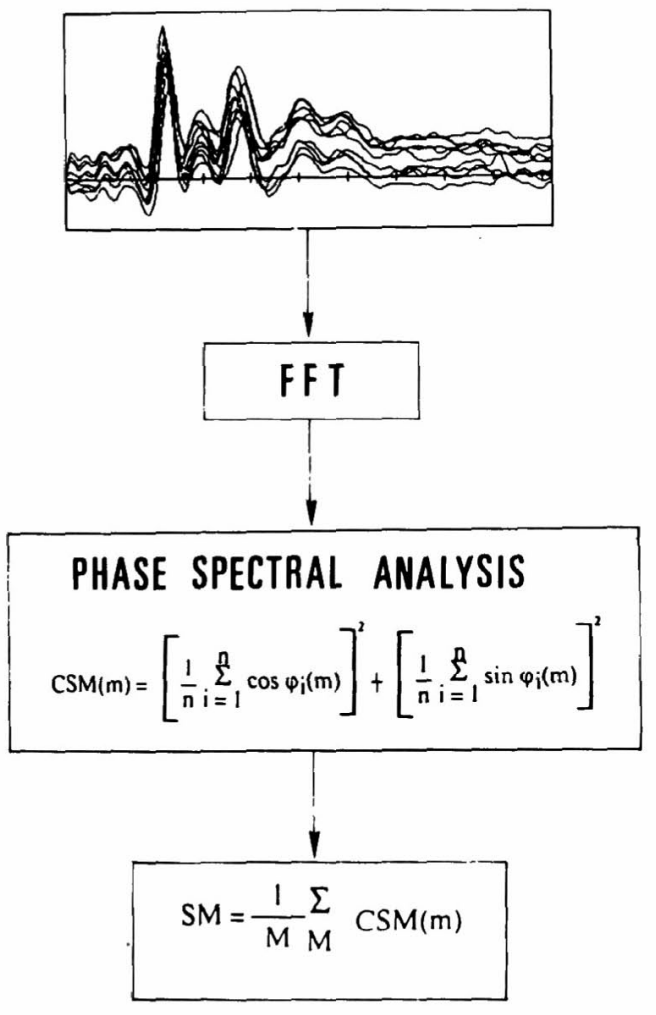

国 13

Phase spectral analysisのブロックダイアグラム 同一刺激条件下に得た 10 個の200回加算による

ABR波形の各々にFFTを行い，図中の式により り各周波数成分の C S M を計算し選出したM個の C

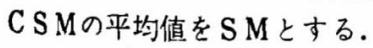

しては phase varianceは大きくなり音刺激に対し time-locked でないという理論に基づくものである.

Fridman $^{14)}$ はこれを応用して ABRの phase spectral analysis を行った, $A B R$ は, しかし $\mathrm{S} / \mathrm{N}$ 比が小 さいので, 同一の方法では ABR 反応が現われている 場合でも phase variance は比較的大きいことから， group averages という考えを導入し，ABRに対する phase spectral analysis を試みた。これは 200 回加算 による 10 の波形を求め,これら 10 の波形データの間 での各周波数の phase variance $[\operatorname{Var}\{\Phi(\mathrm{m})\}]$ を 計算するもので, 1984 年の論文 ${ }^{15)}$ では, 1-Var $\{\Phi(\mathrm{m})\}$ を component synchrony measure (CSM) と呼び, 幾つかの選出された周波数成分の CSM の平

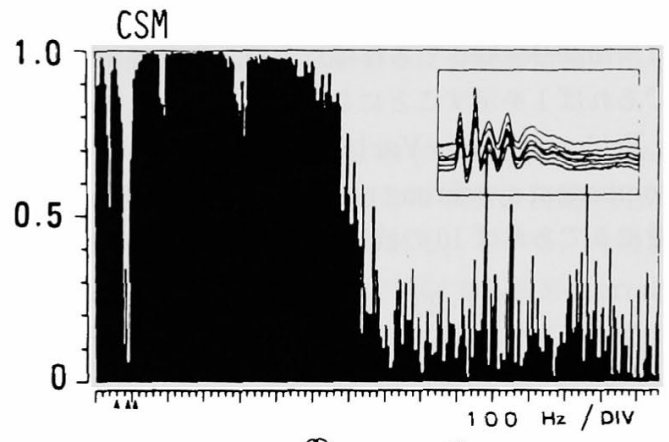

$300 \mathrm{~Hz}$

$\mathrm{CSM}=0.952$

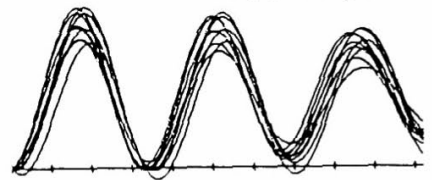

$450 \mathrm{~Hz}$

CSM $=0.058$

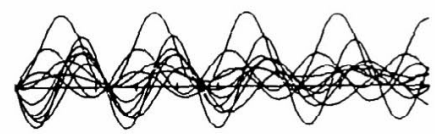

$550 \mathrm{~Hz}$

$\mathrm{CSM}=0.920$

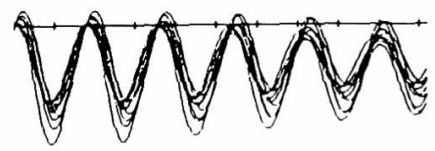

図14

上段：同一刺激条件下に得た 10 個の 200 回加算による A B R 波形と各周波数成分ごとの C S M

下段： $300 \mathrm{~Hz}, 450 \mathrm{~Hz}$ 及び $550 \mathrm{~Hz}$ のC S M と各周波数 成分のみにより合成した波形

C S M 值の高い $300 \mathrm{~Hz}, 550 \mathrm{~Hz}$ の成分による波形間で は位相の同期性が良く, C S M 值の低い $450 \mathrm{~Hz}$ の成分 による波形間では位相の同期性が悪い. 
均を synchrony measure (SM) とし (図 13), ABR 反 応波形の自動検出に応用して, 聴神経腫場の診断, 特 に腫啺の脳幹対側への影響の有無の判定を試みている 15).

Fridman ${ }^{14)}$ が phase variance の算出に用いた計算 式は Mardia のもので,

$\operatorname{var}\{\Phi(\mathrm{m})\}=1-\left[\frac{1}{\mathrm{n}} \sum_{=1}^{\mathrm{n}} \cos \Phi_{\mathrm{i}}(\mathrm{m})\right] \mathrm{z}$

$-\left[\frac{1}{\mathrm{n}} \sum_{\mathrm{i}=1}^{\mathrm{n}} \sin \Phi_{\mathrm{i}}(\mathrm{m})\right]_{2}$

というものである。ここでnはデー夕 (波形) 数で, この場合 10 となる. mは variance を算出しようとす る Fourier component（周波数成分）を示す. $\operatorname{Var}\{\Phi(\mathrm{m})\}$ は $0 \sim 1$ の值をとり，mという周波数成分 の波の位相が, 10 本の波形の間で完全に一致していれ ば（time-locked であれば）０を，完全に at random であれば 1 を示すことになる。

Fridman $^{15)}$ は1-Var $\{\Phi(\mathrm{m})\}$ を

component synchrony measure と呼んだが,この場合 逆に0であれば 10 の波形デー夕間で完全に at ram-

\section{CAT-371 CLICK R-IPSI}
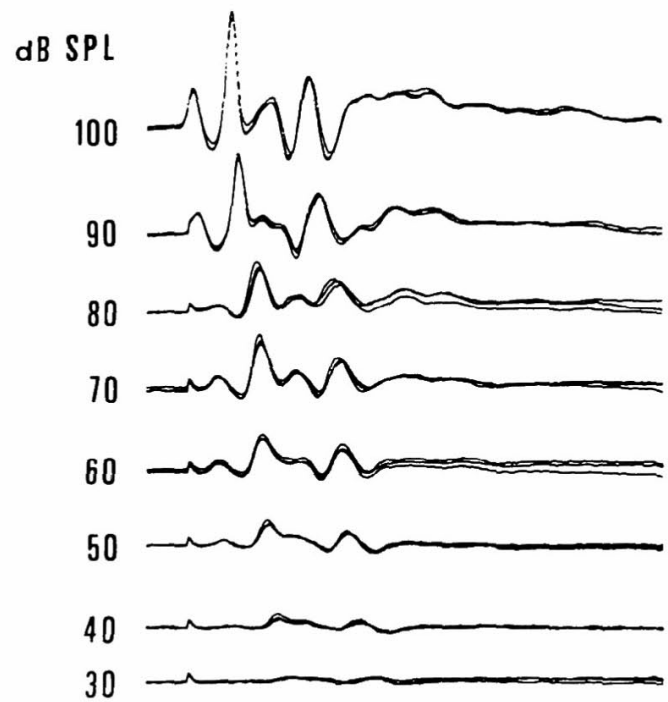

0

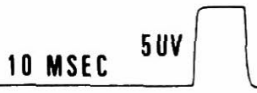

図 $15^{\circ}$

100〜0 dB SPLのクリック音に对する1000回加算の 亦コ A B R 波形 domであることを示し，1であれば完全に一致するこ とになる。

我々は猫の ABRについて同様の分析を行った2. 図 14 の上段にクリック $100 \mathrm{~dB} \mathrm{SPL}$ 刺激時の 10 本の $\mathrm{ABR}$ 波形群とその CSM を示す. $24.41 \mathrm{~Hz}$ ごと约 $7800 \mathrm{~Hz}$ までの各周波数成分の CSM を示すが, 4000 $\mathrm{Hz}$ 付近まで各周波数成分とも大きな CSM を示し, $200,450,900,2000 \mathrm{~Hz}$ に谷が見られる. 図 14 の下段 には $\Delta$ 印の周波数成分のみから IFFTにより得られ た合成波形とその CSM を示す. CSM の大なる 300 $\mathrm{Hz}, 550 \mathrm{~Hz}$ では 10 本の波形間で, 位相が良く一致し， この周波数成分が音刺激に対し time-lockedであり, $\mathrm{CSM}$ の小さな $450 \mathrm{~Hz}$ では 10 本の波形間で位相のず

COMPONENT SYNCHRONY MEASURE CAT 390
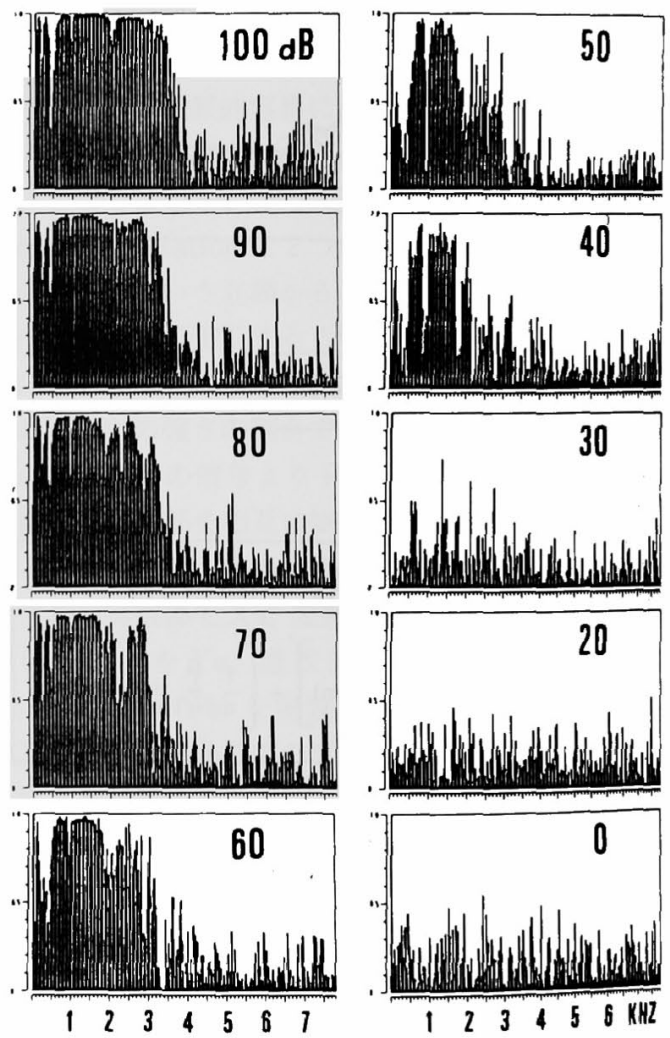

図16

図15と同一のデータにより求めた各音圧ごとの各周 波数の C S M

60dBまでは0〜 4000Hzの成分でC S M は高值を示し， 域値付近では500 1500Hzの成分でC S Mが高值を示 す. 
れが大でり, time-lockedでないことが分かる.図 15 に100 30 dB SPL 及び無刺激下の ABR 波形（各々 1000 回加算）を示す. 同一刺激条件下の ABR 波形の CSM を図 16 に示したが, 音圧が小さくなるに従って $2000 \sim 4000 \mathrm{~Hz}$ の CSM が低下し，域值付近では $500 \sim 1500 \mathrm{~Hz}$ の周波数成分の CSM が無刺激下のそ れと差を示した， $0 \sim 1500 \mathrm{~Hz}$ の CSMの平均值を $\mathrm{SM}(1500 \mathrm{~Hz}), 0 \sim 4000 \mathrm{~Hz}$ の CSM の平均値を $\mathrm{SM}$ $(4000 \mathrm{~Hz})$ とし, 5 匹の猫について音圧ごと SM $(1500$ $\mathrm{Hz})$ と SM $(4000 \mathrm{~Hz})$ の平均值と標準偏差を図 17 に 示したが，域値付近でSM は急に減少していることが 分加る。

ABR の場合, パワースペクトルでは $0 \sim 1000 \mathrm{~Hz}$ の 間に 3つのピークを有することは周知のことだが, CSMでもこれらのピークに一致してCSM 值が高い 周波数成分があり，逆にパワースペクトルの谷に当た る周波数では CSM か゚低い值をとることから，Frid-

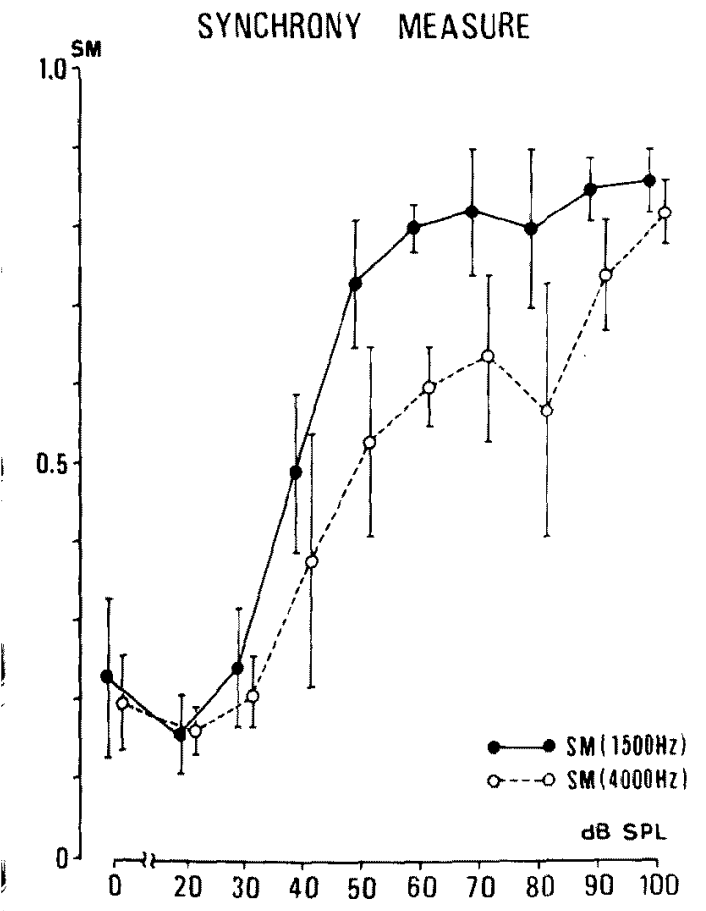

\section{図17}

正常ネコ 5 匹の $\mathrm{S} \mathrm{M}$ 平均値と標準偏差

$\mathrm{SM}(1500 \mathrm{~Hz})$ は $0 \sim 1500 \mathrm{~Hz}$ の周波数成分のC S M 平均值、 $\mathrm{SM}(4000 \mathrm{~Hz})$ は $0 \sim 4000 \mathrm{~Hz}$ の周波数成分の C SMの平均值を示す。 $\operatorname{man}^{157}$ は無刺激時の各周波数成分の CSM とそれらに 相当する周波数成分の有刺激時の CSM との間の有意 差を Mann-Whitny Test（U test）により検討し，無 刺激時と有刺激時の CSM 間に有意差の存在する 6 つ の周波数成分 $(320,480,560,880,960,1040 \mathrm{~Hz})$ を選出し，これらの CSM の平均を synchrony measure（SM）としている.

Fridman一派はこれによりABR 反応域值の自動 判定 ${ }^{16)}$ の他, 中枢障害に関する㟝断 ${ }^{15)}$, 手術中のモ二 タリング39)などへの応用について報告している。しか し，我々の行った猫の下丘破壤での CSM 変化を見 る実験から判定する限りにおいては，ABR波形より 得られる従来加らの波消失, 潜時の延長といった情報 以上の情報は CSM からは得られず, Zappulla ${ }^{399}$ の論 文でも脳幹障害の状況を判断するに有用な情報は得ら れていないようである。

従って, 現在のところ ABR の phase spectral analysis 注 ABR 反応の有無，すなわち域値の自動判定に のみ応用が可能てあると考えられる。しかし，今後更 に加算回数，同一刺激条件下で検討する波形（group averages）の数，サンプリングタイム，サプリング点

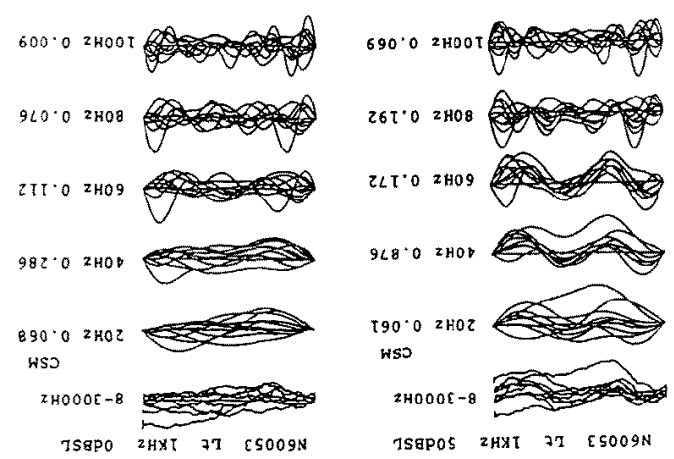

图 $1840 \mathrm{~Hz}$-ERP $の$ Phase spectral analysis 问一刺激条件下で得た各々 10 個の波形群 刺激意は $1 \mathrm{kHz}$ Tone burst 左側は50dBSL，右側は $0 \mathrm{dBSL}$ 再上段の波形群はアナログフィルターのみを 加たもの

2 段目以下は各周波数成分のみで合成した波 形群とそのC S M を示す。

有刺激時には $40 \mathrm{~Hz}$ の成分のC S M が他に比し て高く，無刺激時では各成分の C S M は同樣 のレベルにある。 


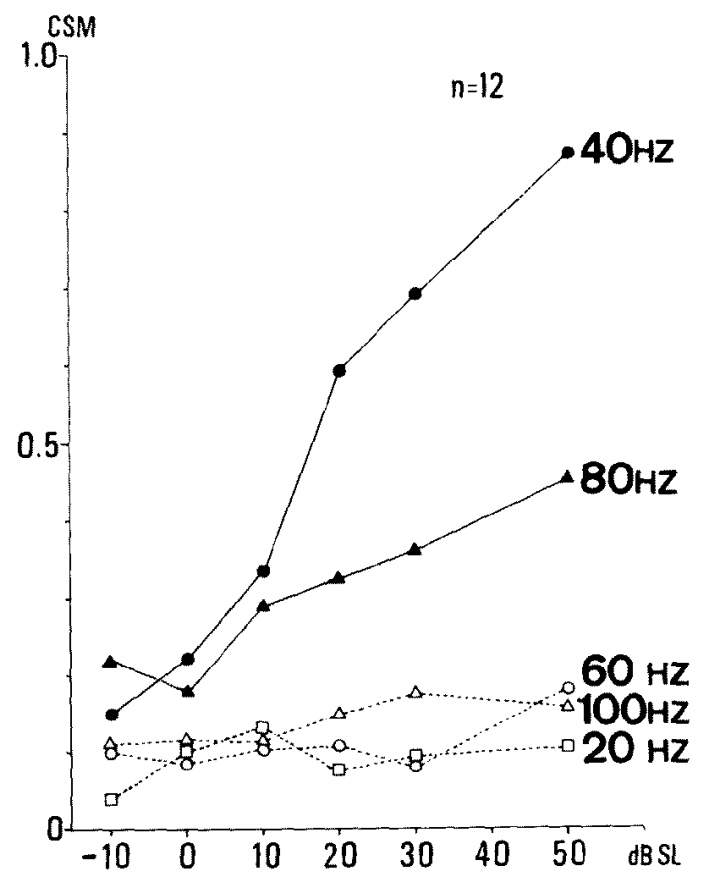

图 $1940 \mathrm{~Hz}$-ERP $の$ Phase spectral analysis $1 \mathrm{kHz}$ トーンピップに対する音压ごとの20ー $100 \mathrm{~Hz}$ の各周波数成分の C S M の変化を示寸。 $40 \mathrm{~Hz}$ の成分は他の成分と比較して音压の変 化に良く比例している。

数, 刺激音, 刺激間隔などの検査条件, U値の criteria のとりかたなどの計算条件など，十分検討する必要が あると考える。

また, 我々は現在 $40 \mathrm{~Hz}$ 事像関連電位への phase spectral analysis の応用を試みている。詳細について は別に報告する予定だが，約 $20 \mathrm{~Hz}$ の周波数分析能で $40 \mathrm{~Hz}$ を中心とした周波数成分の CSM 単独でも反応 波形の自動判定は可能であろうと考えられた。(図 18 , 19)

\section{5. その他}

FFTの応用法としては, 他にコヒーレンス関数の計 算，ケナフストラムス（信号のパワースペクトルの対数 の FFT)などがあるが，聴性電気反応への応用の報告 は見られないので省略する。

\section{まとめ}

$\mathrm{ABR}$ を中心に聴性電気反応におけるフーリ工変榾 法の利用の現況について次の 4 項目に分けて概説し た.

(1) デジタルフィルター：現在, FFT の最も一般的な 利用法であり，これにより同一ABR 波形データから 速波成分，緩徐波成分を分䧿することが容易にでき， 設定によっては従来，出現率の低いとされたII波・IN 波の検出率を高めることが出来る。

（2）パワースペクトル；現段階ではこれのみにより鹥 床的に有意義な情報柱得難いが，ABR では 3 峰性を 示すパワースペクトルの各峰を中心とする周波数成分 からIFFTにより緩徐波成分，中間波成分(位称)，速 波成分に分離して解析することは有意義と考えた。

(3) cross correlation：2つの信号間の関保を位相と いう立場から見るもので，多発性硬化症の診断への応 用, $A B R$ の自動判定への応用など，今後，瓳床応用が 期待される。

(4) phase spectral analysis；同一刺激条件下の幾つ かの波形群の間で一定の周波数成分の Phase variance を計算し，その周波数成分が刺激に対してどの程度 time-lockedであるかにより反応の有無を判定しょう とするもので，ABRの自動判定への応用など臨床応 用が検討されている。

\section{参考 文 献}

1）青柳 優, 横山寿一, 布施健生：聴性脳幹反忘の新しい パラメータとしての Synchrony measure 法について。 Audiology Japan 28: 242 250, 1985.

2）青柳 儤, 横山寿一, 酒井 仁, 鈴木利久: Phase spectral analysisに上るABR 波形域值検出法の顺㣙. Audiology Japan : 印刷中.

3) Arslan $E$, Prosser $S$ and Michelini S: The auditory brainstem response to binaural delayed stimuli in man. Scand Audiology $10 ; 151-155,1981$.

4) Barajas JJ : Brainstem response audiometry sa subjective and objective test for neurological diagnosis. Scand Audiology $14: 57-62,1985$.

5) Beagley HA, Sayers B Mca and Ross J: Fully objective ERA by phase spectral analysis. Acta otolaryngol 87: 270-278, 1979.

6) Davis AE : Power spectral analysis of flash and click evoked response. Electroenceph clin Neuro. 
physiol 35: 287-291, 1973.

7) Doyle dj and Hyde ML: Digital inverse filtering of distored auditory brainstem responses. Scand Audiol $10: 261-263,1981$.

8）江原義郎，河村正三，市川銀一郎：聴性頭頂部緩反応の デシタルフィルターによる分析. Audiology Japan 25: 208-217, 1982.

9）江原義郎，市川銀一郎，板橋隆嗣，原田克己：デジタル 処理法による聴性誘哞反応の分析。医用電子と生体工 学 $30: 174-180,1983$.

10）江原義郎, 河村正三, 市川銀一郎 他：聴性脳幹反心の 動態分析. Audiology Japan 26: 493-494, 1983.

11）五原義郎，市川銀一郎，安藤一郎，金俊治：聴性腅幹反 応 (ABR) 2 大成分の反応動態分析一刺激音性状との 関係を中心に-Audiology Japan 28 :228-236, 1985.

12) Elberling $C$ : Auditory electrophysiology : The use of template and cross-correlation function in the analysis of braistem potentials. Scand Audiol 8: 187-194, 1979.

13) Elberling C: Auditory electro-physiology: Spectral analysis of cochlear and brain stem evoked poten. tials. Scand Audiol $8: 57-64,1979$.

14) Fridman J et al : Application of digital filtering and automatic peak detection to brain-stem auditory evoked potential. Electroencephalography and clinical neurophysiology $53: 405-416,1982$.

15) Fridman J et al : Application of phase spectral analysis for brainstem auditory evoked potential detection in normal subjects and patients with posterior fossa tumors. Audiology $23: 99-113,1984$.

16) Greenblatt et al : Response threshold determination of the brain stem auditory evoked response: A comparison of the phase versus magnitude derived from the fast Fourier transform. Audiology $24: 288$ $-296,1985$.

17) Hamming RW 著宮川洋, 今井秀樹訳 : デジタル・フ イル夕、科学技術出版社，果京，1980.

18）市川銀一郎, 河村正三, 西田正剛 他：パワースペクト ルから見た頭頂部緩反心応愦陽性.Audiology Japan $20: 435-436,1977$.

19) Jervis $\mathrm{BW}$ et al : A fundamental investigation of the composition of auditory evoked potentials. IEEE Transactions on biochemical engineering 30 , $1: 43-50,1983$.

20) John ER et al: Normative values for brainstem auditory evoked potentials obtained by digital filter- ing and automatic peak detection. Electroencephalography and clinical neurophysiology $54: 153-$ $160,1982$.

21）加藤栄一，市川鋸一郎，森福孝之，江原義郎：実験的異 常 ABRのパワースペクトル. Audiology Japan 28 $5: 784-789,1985$.

22）加藤寿彦，曾田鼻二，松尾正彦，池田公，白石君男： Slow component の各周波数領域におけるパワースペ クトルについて. Audiology Japan 19：411-412, 1976.

23) Kevanishvili $Z$ and Aphonchenko V:Frequency composition of brain stem auditory evoked potentials. Scand Audiol $8: 51-55,1979$.

24) Lang AH, Jaentti $V$ and Happonen JM : The application of FFT and inverse FFT in the analysis of ABR waveform variation.Scand Audiol Suppl 13: 65-67, 1981.

25）間宮真佐人，西川利男：化学計湘のためのフーリエ変 換法入門。共立出版，東京，1983.

26) Maurizi $M$ et al : Contribution to the differentiation of peripheral versus central tinnitus via auditory brain stem response evaluation. Audiology $24: 207-$ $216,1985$.

27）宮川 洋 他：デジタル信号処理。電子通信学会編, コ ロナ社, 東京, 1975 .

28）神律卓二, 六郷正暁：ABRのパワースペクトルによる 解析. Audiology Japan $24: 493-494,1981$.

29) Paludetti $G$ et al : Auditory brain stem response (ABR) in multiple sclerosis. Scand Audiology 14: 27-34, 1985.

30) Sayers B McA, Beagley HA and Riha J : Pattern analysis of auditory evoked EEG Potentials. Audiology $18: 1-16,1979$.

31）曾田豊二, 調重昭, 池田公 他：周波数分析的㨫波誘発 反応のデジタル処理について. Audiology Japan 18： $383-384,1975$.

32）末続義幸，河村正二，市川銀一郎 他：頭頁部緩反応 (ERA) の周波数仔析による判定の試み、Audiology Japan $19: 407-408,1976$.

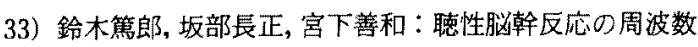
分析. Audiology Japan 24:173-177, 1981.

34）鈴木篤郎, 小林潔子, 平林源：㯖性脳幹反応の周波数分 析一刺激音強度および刺激間隔と反応周波数成分との 関俰-. Audiology Japan 25:631-635, 1982.

35）鈴木篤郎 他：揌性脳幹反応「その基嘫と臨床」メジカ $ル ヒ ゚ ュ ー$ 社, 東京, 1985 .

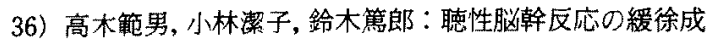


分一刺激音強度及び刺激間隔との関係一. Audiology Japan $26: 716-721,1983$.

37) 内田利男, 河村正三, 市川銀一郎 他：速反応(ABR, MLR) に扔けるパワースペクトル解析. Audiology Japan $23: 231-232,1980$.

38）山本香列，坂部長正：頭頂部緩反応の周波数分析に上 万研究. Audiology Japan 20:200-205, 1977.

39) Zappulla $R$ et al : A quantitative assessment of the brain stem auditory evoked response during intra. operative monitoring. Neurosurgery $152: 186-191$, 1984.
稿を終わるに臨み，御校閲いただいた小池吉郎教授に深 く感謝致します。また，図の一部を御提供いただき，論文作 成にあたり多くの御助言をいただいた順天堂大学医学部耳 鼻咽喉科市川銀一郎先生，並びに同大学医学部中央電算機 室江原義郎先生に深謝致します。

(原稿受付 昭和 60.12 .23 日急载)

別剧請求先 ₹ 990-23 山形市藏王飯田字西の前 山形大学医学郎耳悬颔喉科学教室青㧕 脣 